\title{
Rural poverty in Mexico: assets and livelihood strategies among the Mayas of Yucatán
}

\author{
Nigel Poole ${ }^{1 *}$, Remi Gauthier ${ }^{2}$ and Aliza Mizrahi ${ }^{3}$ \\ ${ }^{1}$ SOAS Centre for Development, Policy and Environment, and London International Development Centre, University \\ of London, UK; ${ }^{2}$ Agra CEAS Consulting, Centre for European Agricultural Studies, Imperial College London - Wye \\ Campus, Wye, Kent, UK; and ${ }^{3}$ Independent Consultant, Calle 49 no. 481, Mérida, Mexico
}

\begin{abstract}
Understanding poverty and sustainability needs livelihood studies that acknowledge heterogeneity at the community and household level. This is particularly true for Latin America where inequality and ethnicity are important aspects of poverty and sustainability. This paper is a detailed examination of the natural resources, socio-economic assets and livelihood strategies of two Mayan communities of the Mexican State of Yucatán. There were three fundamental objectives: to elucidate the people's perceptions of poverty, to analyse their resource use and livelihood strategies, and to suggest ways in which access to markets can reduce poverty and enhance sustainable development. Using qualitative and quantitative methodologies, the dominance of certain successful strategies are made clear. First, milpa - the traditional system of maize production - is a way of life for the Mayas. Secure access to maize-producing land is a valuable asset, partly because it also attracts government subsidies. Second, ownership of small livestock is also part of Mayan life. Ownership of other assets such as beehives gives access to (relatively) lucrative product markets. Third, active agribusiness marketing also requires assets: ownership of transport services; finance to assemble and sell products such as forest fruits, honey and maize; business skills and an ability to create commercial linkages to traders. Appropriate interventions for different wealth groups are suggested to enhance sustainable development of the communities.
\end{abstract}

Keywords: poverty, Mexico, natural resource assets, livelihood strategies, indigenous, market access

\section{Introduction: poverty, inequality, ethnicity and sustainability in Latin America}

\section{Poverty, inequality and ethnicity}

Global poverty is most intractable in marginal rural communities where geographical remoteness affects the quality of public services and private opportunities, cultural barriers reduce the quality of governance and civic participation, and a fragile natural resource base is subject to

* Corresponding author. Email: N.Poole@soas.ac.uk unsustainable economic and ecological exploitation. Latterly, the Millennium Development Goals (MDGs) have catalyzed interest in global poverty reduction to, inter alia, 'eradicate extreme poverty and hunger' (Goal 1). This interest is partly attributable to the simplicity of the 'one dollar a day' target, which has the considerable attractions of ease of communication and comprehension.

Simplicity is sometimes problematic. To halve 'the proportion of the population living on less than $\$ 1$ per day' (1993 PPP) ${ }^{1}$ is only Indicator 1 of the MDG poverty target. Indicators 2 and 3 are more nuanced approaches to assessing 
poverty because they embrace elements of inequality and not just (more or less) absolute poverty. Inequality matters, even in countries not usually considered to be poor, ${ }^{2}$ and justifies attention to Indicators 2 and 3 as well as the current popular MDG indicator (Poole, 2005b).

Of the major regions of the world, inequality in income distribution is greatest in Latin America, and poverty is intractable (Besley \& Burgess, 2003; Chen \& Ravallion, 2004; Wolfensohn \& Bourguignon, 2004; World Bank, 1990). Poverty and inequality in Latin America, as in other regions, are closely linked to another phenomenon, ethnicity. Reviewing Mexico's progress towards the MDGs, Fuentes and Montes (2004) reiterated the stark regional disparities and north-south divide in terms of education, infrastructure and poverty, with the indigenous groups worse off in respect of poverty, illiteracy levels, gender equity and basic infrastructure. In regions of intractable rural poverty with a resource base subject to unsustainable exploitation, indigenous peoples are overrepresented (World Bank Institute Poverty and Growth Blog, no date). Achieving sustainability and international development goals in such areas requires, inter alia, substantial livelihood investments. 'The extent and persistence of poverty in many ways depends on whether poverty among indigenous peoples can be reduced by 2015' (IFAD, no date).

\section{Poverty, ethnicity and sustainability}

Eradicating poverty must be linked to other imperatives. It is Goal 7 of the MDGs that addresses sustainability, specifically Target 9: to 'integrate the principles of sustainable development into country policies and programmes and reverse the loss of environmental resources'. While there is no explicit linkage between Goals 1 and 7, the linkages between development, resource use and the sustainability literature can be traced back through the Brundtland Commission (World Commission on Environment and Development, 1987) to the 1972 UN Conference on the Human Environment (Organisation for Economic Co-operation and Development and United Nations Development Programme, 2002). There is now a substantial literature on the concept of sustainability not only in relation to the natural environment but also in relation to the social environment, and particularly concerning peoples whose livelihoods are intimately connected with the conservation and use of natural resources. This research output also covers regions of intractable rural poverty with a resource base subject to unsustainable exploitation, and where indigenous or tribal peoples are over-represented (World Bank Institute Poverty and Growth Blog, no date).

Poverty, livelihoods, markets, policies and people are all linked to the sustainability literature. For example, Nath et al. (2006) examined how the shifting cultivation practices of tribal people in the Chittagong Hill Tracts of Bangladesh contribute to the people's livelihoods, and noted the ineffectiveness of previous public policies to promote livelihoods and sustainable resource use. Working among tribal peoples in southern India, Shaanker et al. (2004) argued that the ecological costs to fragile ecosystems of livelihood gains for the poor can be attenuated by policy approaches which themselves must be informed by an understanding of the sociocultural context of the people and of the economics of market operations into which natural resource products are sold. Sustainability issues among innovating Latin American communities were addressed by Nicklin et al. (2006) who examined supply chains for lupin in Ecuador to assess the agronomic and livelihood benefits for poor producers. Haggar et al. (2005) evaluated the economic and technical opportunities for agroforestry in three communities in the southern Yucatán Peninsula of Mexico and found that there was no single optimum production strategy but that sustainable options depended on location-specific variables and also on individual farmer characteristics.

Research on poverty, sustainability and the 'ethnic gap' in Latin America is timely (Poole, 2005 b), not least because of the strong political dimension (Andolina, 2003; Tilley, 2002; van Cott, 2003; Washbrook, 2005). The indigenous Zapatista uprising in Mexico during the 1990s highlighted dramatically the need for empowerment, inclusion and equitable socio-economic and sustainable development policies. According to Villafuerte Solís (2005: 480), there has been no discernible political development since, and the most vulnerable sectors of the population 'currently have little prospect of an improvement in their 
impoverished living standards'. This article presents new knowledge from a study of poverty and heterogeneity, natural resource use, livelihoods, markets and policies among agricultural and forest-dependent indigenous Mayan communities in Yucatán, Mexico.

\section{Aggregate studies and the need for disaggregation}

Studies of poverty and inequality in Latin America have tended to take an aggregate view. For example, de Janvry and Sadoulet (2000) analyzed household income and household-level asset data from Mexican ejidos to show the role of assets in explaining income sources and rural poverty. Uncontroversial results showed that rural incomes and poverty are explained by the asset endowments and the contexts where assets are used. It is evident that 'contexts' need disaggregating, and that there would be advantages from a richer data set to capture the variations in terms of range of assets, subsistence and income sources, cultural and physical barriers and potential strategies. Nevertheless, on the basis of the results, they suggested four exit paths from rural poverty:

(1) Migration: exit from rural areas to the nonpoor urban economy.

(2) Agriculture: the traditional development path for rural people endowed with natural, social and institutional assets above a critical level who can engage with the wider economy.

(3) Pluriactivity: diversification that combines agriculture with off-farm incomes.

(4) Assistance: alternative approaches include:

- one-time transfers to assist the poor out of a low level equilibrium;

- transfers of resources to move the chronically poor into 'sustained welfare'; and

- safety nets to combat the effects of shocks such as personal, natural and economic disasters.

On poverty exit strategies, Martínez (2004) cast a critical eye over the situation of the Andean campesino ( $=$ indigenous) population in the globalizing economy and criticized de Janvry and Sadoulet's (2000) model of exit strategies for the Latin
American poor for its unrealistic assumption that there is a proactive and enlightened state with policies of effective decentralization and empowerment of rural society. Moreover, he argued that market opportunities will be exploited - probably unsustainably - through powerful external economic forces. A local perspective requires a more solid analysis of the resources, of the dynamics of change, of conflicts associated with rural peoples' own initiatives, and of tensions arising from the unequal capital endowments between rural populations and the surrounding society.

On context, an important outcome of work among the poor in Central America has been the high priority the people themselves gave to the production of food crops for home consumption, because of the high opportunity cost of subsistence compared with risky commercial production in regions of high transaction costs (Wadsworth et al., 2004). For marginalized regions and peoples facing high transactions costs and entry barriers, the prospects for successful integration into the wider - not to say global - economy, are problematic. Policies may need to be targeted at the local economy, with an institutional framework that nurtures the local 'infant markets' and 'infant economies', and an emphasis on interventions based on a deep understanding of local conditions (Poole, 2004, 2005b; Poole \& Penrose Buckley, 2006).

\section{Disaggregated studies}

A fuller understanding of the local context is likely to suggest a number of hypotheses about poverty exit strategies: for example, alternative pathways may not be equally available to apparently similar communities; there is no single appropriate pathway for all households within a given community; and a single pathway can have differential effects within a given household. A range of strategies for more or less 'prosperous' and 'marginal' regions is called for (Wadsworth et al., 2004).

Disaggregated studies are needed that uncover institutional and other parameters of poverty and drivers of growth at a local level, using countryspecific and sub-national data (Besley \& Burgess, 2003; Ravallion, 2004). Notwithstanding the use of local poverty lines for assessing absolute poverty - which is nothing new (Ravallion et al., 
1991) - people are likely to have their own perceptions of poverty, including natural resource assets and strategies. These also need to be teased out and evaluated at a local level, not least because they will influence the feasibility of and choice among poverty exit strategies. Hentschel and Waters' (2002) work in four Ecuadorian highlands communities is one such 'contextual' village study that investigated and acknowledged inter- and intra-village heterogeneity. This study in Mexico adds to this literature.

\section{The research context: sites and people}

This paper reports a detailed examination of poverty and livelihood strategies of the forestmargin dwelling Mayan people of the southeastern Mexican State of Yucatán. There were three fundamental objectives - conceptual, empirical and policy - to the investigation: to elucidate the people's perceptions of poverty, to analyse their livelihood strategies and natural resource use, and to suggest ways in which market access for natural resource products can reduce poverty. The paper proceeds by giving an account of the research context, followed by an outline of the methodology next, the exploratory analyses, multivariate tests for data consistency and validation of the poverty concepts and the final discussion and implications.

The research was conducted in the Mayan villages of Mahas and Poop, Municipality of Tixcacalcupul, between 1999 and 2002. The Mayan peoples are among the most vulnerable of Mexican population groups. Despite their poverty, these communities are noted for their strong social cohesion, manifest in the highly functional community institutions, such as reciprocal labour relations, inter-generational socialization and strong cultural and linguistic identity (de Frece, 2006).
Historically, the Yucatán Peninsula has been poorly linked to the rest of Mexico. Integration has accelerated in the last two decades, spurred by international tourism. Roads are asphalted, but distances to commercial centres are appreciable and public transport services are poor, such that the study communities are somewhat isolated (Table 1). From Mérida, the State capital, to Mahas and Poop is a distance of approximately $220 \mathrm{~km}$.

Agriculture in the Yucatán Peninsula dates back to at least $2000 \mathrm{BC}$ (Edwards, 1986). Vegetation is dry tropical forest, soils are scarce and shallow, and climate is dry sub-humid, with mean annual rainfall around $1100 \mathrm{~mm}$, but highly variable from year to year. Social organization and land tenure are based on the ejido system, whereby members are given usufruct rights to plots of agricultural land and communal rights to non-agricultural land (forest and pasture). The structure of the ejido is democratic and members are either signatories to the act of establishment (certificados) or are their descendants (usufructuarios). The ejidos were established in 1954 (Poop) and 1962 (Mahas) respectively.

Historically, the Mayan peoples developed a highly sophisticated natural resource management system (Gómez-Pompa, 1987; Gómez-Pompa \& Kaus, 1990). The people are still farmer/ harvester/collectors for whom the natural forest and milpa (small-scale slash and burn maize cultivation system mixed with beans, squash, root crops, and fruits) constitute the principal natural livelihood resources and activities, and have a strong cultural significance. Five types of land tenure are recognized:

(1) The home garden, or solar, is private land, and products can be sold without constraint.

(2) The milpa is ejido land, primarily for maize cultivation, for which there is a government

Table 1 Distances between local and regional sites

\begin{tabular}{|l|l|l|l|r||}
\hline \hline From & & To & & km \\
\hline Mérida & State capital & Valladolid & Municipal capital & 159 \\
\hline Valladolid & Municipal capital & Mahas & Study village & 49 \\
\hline Mahas & Study village & Poop & Study village & 8 \\
\hline
\end{tabular}


subsidy of about $\$ 650^{3}$ per hectare per year; effectively, milpa is private land.

(3) Caña (or cañada) is milpa but after one year of cultivation - therefore less productive - and attracts a slightly lower per hectare subsidy of about $\$ 550$.

(4) In both villages, the communities have set aside private land for agroforestry - not common elsewhere - that they call the parcela.

(5) The forest land is communal - firewood, timber and non-timber forest products (NTFPs) can be collected for private use but the community assembly must agree commercial use of any forest products. In Poop a reserve has been set aside, to be maintained free of exploitation.

Tree- and forest resources are culturally and economically significant, and households use timber from forest sources for construction and firewood. Among the NTFPs that generate cash incomes, the most important are honey, fruits and huano (grass) for thatching. Medicinal plants are also important for subsistence (Gauthier \& Poole, 2003).

\section{Research methodology}

Investigations were conducted in four stages. First, an initial participatory appraisal was conducted to introduce the research to the communities while gathering information about the community institutions, social structures, issues and physical layout. Activity calendars, community resource mapping, institutional mapping using Venn diagrams and semi-structured interviews were conducted during this phase. Both Maya and Spanish languages were used.

Second, a wealth ranking exercise was conducted in Mahas and Poop by researchers from the Universidad Autónoma de Yucatán using the process outlined in Grandin (1988). Wealth ranking is a participatory technique the results of which can be compared with quantitative measures to test the robustness of the relationship between the self-assessment and simple quantitative indicators. Results were presented to the communities for verification by both communities, compared and combined to give a consolidated wealth ranking to facilitate comparison between the communities.
Third, a two-stage questionnaire survey was implemented in each village covering household livelihoods. This survey constituted the main part of the livelihoods study by providing baseline data on $25 \%$ of families in each of the communities. Twenty-six families were interviewed in Mahas, and 25 families in Poop.

The final phase of the research was used to verify the data obtained by discussing preliminary results with the communities. One family was found to be a relatively 'wealthy' outlier and this case was investigated in greater depth by informal interview. Informal interviews were also conducted with the intermediaries who purchase forest products in the region.

\section{Triangulation and representativeness}

Subsequently, intercommunity comparisons were made between Mahas and Poop and neighbouring villages to confirm the representativeness of Mahas and Poop in relation to other settlements in the 'Mayan zone' of the Yucatán peninsula (the neighbouring Mayan indigenous communities and the adjacent predominantly indigenous municipalities of Tepich and Tihosuco in Quintana Roó State). Two sources of data were used: secondary socio-economic data collected at the level of the local municipality for nine villages; and data from the latest INEGI (Instituto Nacional de Estadística, Geografía e Información) census were analysed (INEGI, 2000).

\section{Data analysis}

Exploratory analysis of the data was conducted using descriptive and analytical procedures within SPSS including boxplots, cross-tabulations and one-way ANOVA to understand the nature of wealth, poverty and livelihood strategies. A Mann-Whitney $U$-test was used to compare the wealth strata data of the two communities. Further analyses used multivariate techniques of cluster, factor and regression analysis to validate the data and concepts.

A series of three multivariate analyses was conducted to assess the explanatory value of the wealth ranking concept and its consistency with the primary data set focused on incomes: 
(1) Cluster analysis was used to classify 51 households from the two communities on the basis of ten variables of income source data. The cluster membership and profiles were then compared with the wealth ranking self-assessment.

(2) Data reduction was undertaken through a series of factor analyses of 34 socio-economic variables to identify the underlying livelihood and income strategies of the samples of villagers from the two communities.

(3) Finally, regression analysis was conducted on wealth ranking data and the livelihood and income factors identified in stage 2 to test the validity of the factors in relation to the community poverty self-assessment.

\section{Results of the exploratory analyses}

\section{Wealth ranking}

The wealth ranking criteria defined by the villagers of Poop reflect people's household asset base and economic strategies in terms of: quality of housing; access to private land in addition to community-managed lands; other physical assets (e.g. livestock ownership); involvement in diverse economic activities such as local employment and migration; the level of self-sufficiency in the staple food, maize; and demographics (age, gender, education and knowledge of health and diseases) (Table 2). In Mahas the community chose to use a reduced set of criteria that excluded health knowledge. Also, they included another higher wealth level ('well-off') and excluded the extremely poor category. For subsequent analysis, the Poop data for very poor and extremely poor were aggregated.

\section{Livelihood survey results}

Twenty-six families were interviewed in Mahas, and twenty-five families in Poop. Respondents were distributed among wealth strata as shown in Table 3.

The well-off stratum was included in the analysis even though it only represented one 'outlier' family. Among the characteristics that set this family apart were that the wife had two husbands, the household owned 50 ha of private land purchased from a neighbouring ejido, owned a pickup truck and managed a successful village retail outlet and a wholesaling business assembling local produce and transporting it to urban markets.

A Mann-Whitney $U$-test to compare the wealth strata data of both communities showed no significant difference between the communities $(U=$ 290.5, $p=0.37$ ) such that the two communities are similar in terms of wealth strata distribution, and suggesting that the differences which occur are found within communities: thus, intra-community heterogeneity is important.

\section{Cash income}

There are two principal reasons among others for asserting that poverty cannot simply be measured by cash income. First, people use a range of economic, social and physical indicators to assess levels of wealth and poverty (Table 2); and second, noncash sources of subsistence may be significant. Nevertheless, cash income is important for practical reasons; poor people need cash for a range of expenses, and also for statistical reasons, cash incomes are often taken to be a proxy, albeit imperfect, for poverty.

The validity of this proximate indicator was found to be robust: cross-tabulation of total cash income and wealth ranking showed a significant relationship ( $p=0.007)$, and a one way ANOVA test gave a significant difference between mean income levels for wealth groups. The boxplot (Figure 1) indicates the median, the quartiles, and extreme values for cash incomes for both villages, excluding the well-off family from Mahas whose income was in excess of $\$ 151,000$ (Mexican).

In addition to material and productive assets and social assets, factors such as household size and demographic structure, and family lifecycle affect perceptions about wealth. A concept of social and economic 'stability' captures significant attributes of a broader concept of 'poverty': the need to migrate for employment, the need to hire labour for essential agricultural activities, the need to sell and buy maize (an item of greater cultural significance than other food products) impose constraints and reduce choices in ways that affect well-being in a negative sense (Table 2). 


\begin{tabular}{|c|c|c|c|c|}
\hline 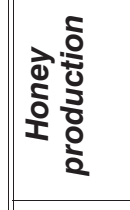 & 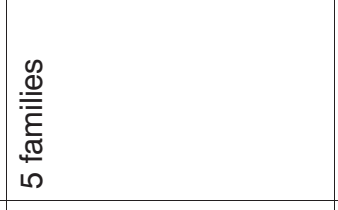 & 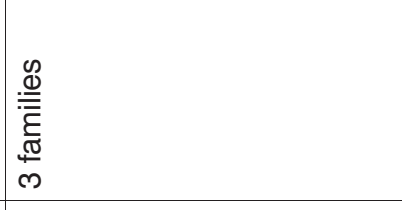 & 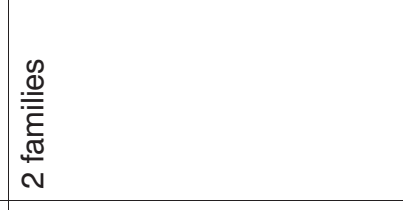 & $\begin{array}{l}0 \\
\text { Oे } \\
z\end{array}$ \\
\hline 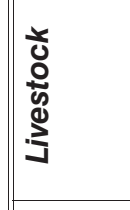 & 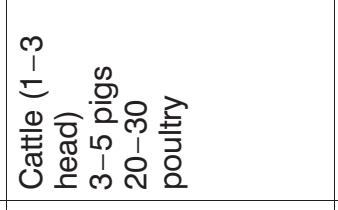 & 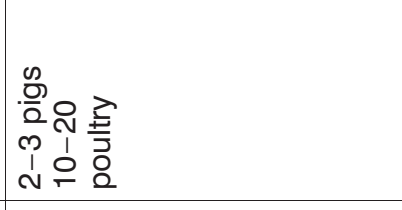 & 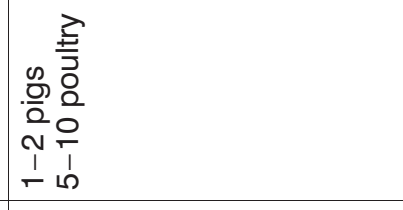 & $\begin{array}{l}\frac{2}{2} \\
\frac{1}{2} \\
\frac{2}{0} \\
0 \\
0 \\
0\end{array}$ \\
\hline 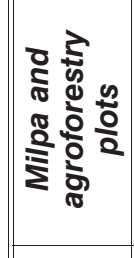 & 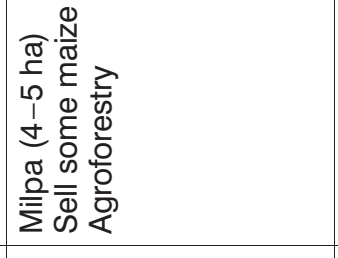 & 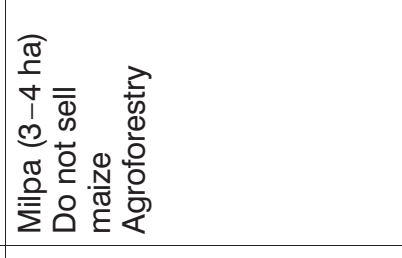 & 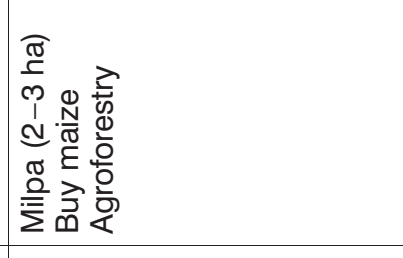 & 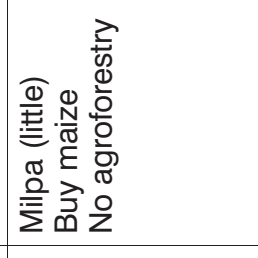 \\
\hline 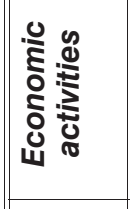 & 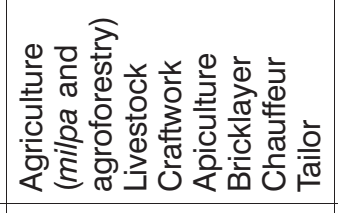 & 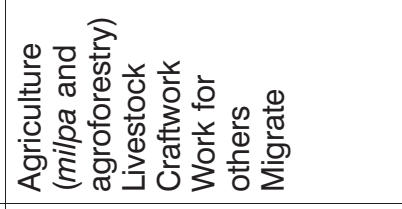 & 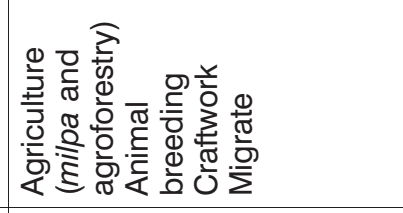 & 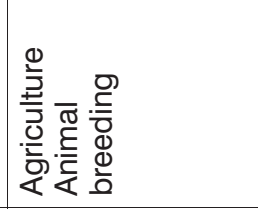 \\
\hline 这 & 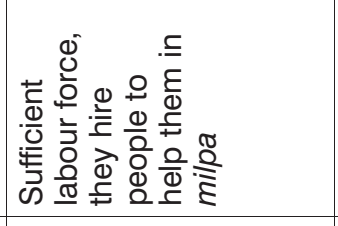 & 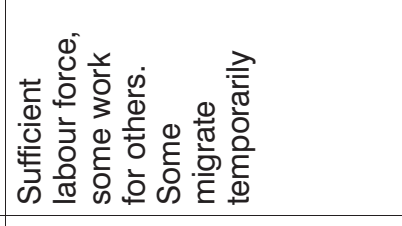 & 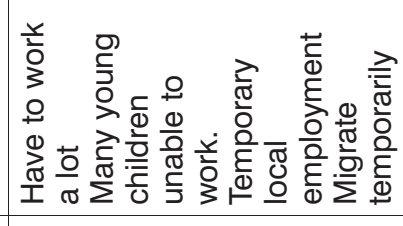 & 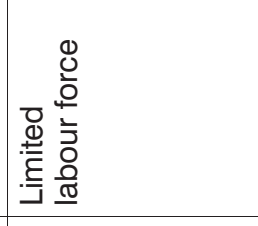 \\
\hline 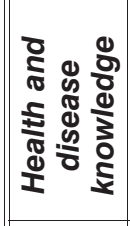 & 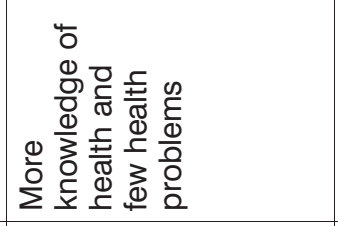 & 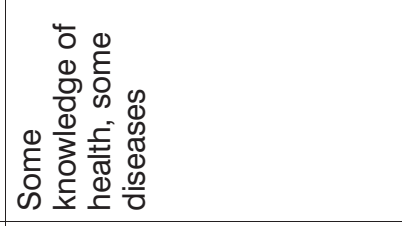 & 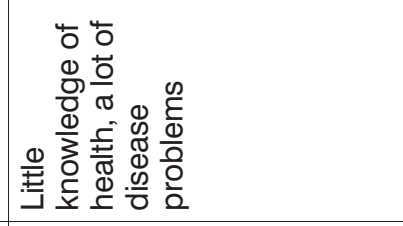 & 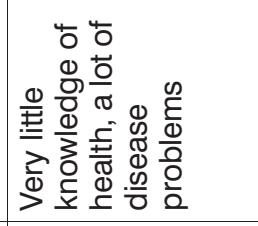 \\
\hline 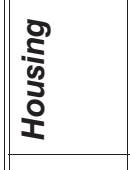 & 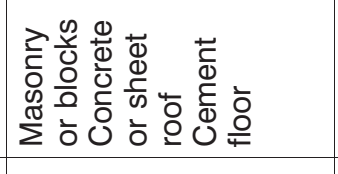 & 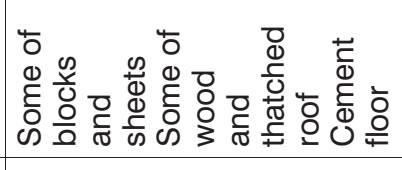 & 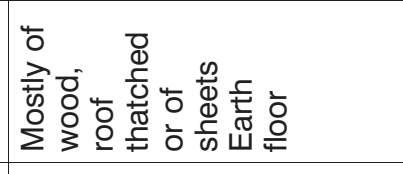 & 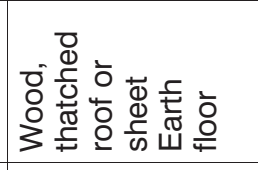 \\
\hline 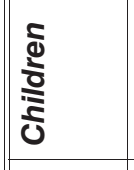 & 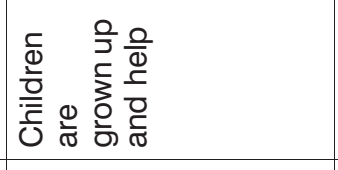 & 至 & 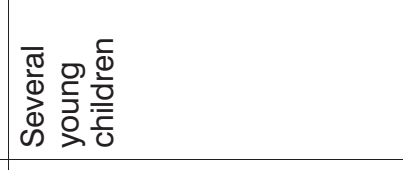 & 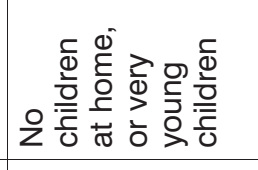 \\
\hline そ) & 尺ి & ল & $\bar{m}$ & $\theta$ \\
\hline 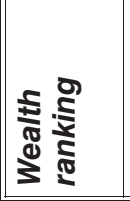 & 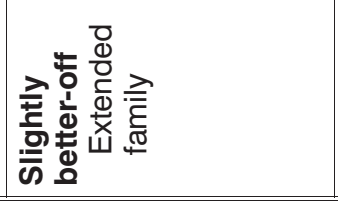 & 产 & 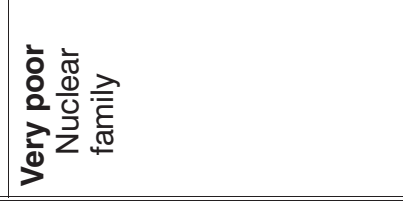 & 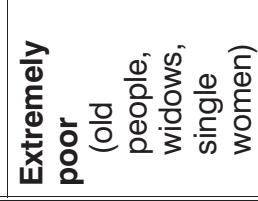 \\
\hline
\end{tabular}


Table 3 Households interviewed by wealth strata

\begin{tabular}{|l|c|c|}
\hline \multirow{2}{*}{ Wealth strata } & \multicolumn{2}{|c|}{ Number of families } \\
\cline { 2 - 3 } & Mahas & Poop \\
\hline Very poor & 3 & 3 \\
\hline Poor & 19 & 21 \\
\hline $\begin{array}{l}\text { Slightly } \\
\text { better-off }\end{array}$ & 3 & 1 \\
\hline Well-off & 1 & 0 \\
\hline
\end{tabular}

\section{Diversity of resources and income sources}

For the economies of the communities as a whole, there is a dominant role of government subsidies for agriculture based on the area of land clearance and maize production, and of cash employment in the peoples' cash generation strategies (Figure 2a). Maize sales from the milpa, NTFPs (principally honey production), crafts and livestock follow in importance.

Disaggregation by economic activity reveals markedly different patterns of income sources between wealth groups (Figure $2 \mathrm{~b}-\mathrm{e}$ ). For the small group of very poor $(n=6)$ the cash income profile highlights the large contribution of government subsidies, comprising half the total. Crafts, livestock sales and NTFPs are next in importance. Income from employment is notably small compared with the aggregate results. Other activities each contribute only a small amount.

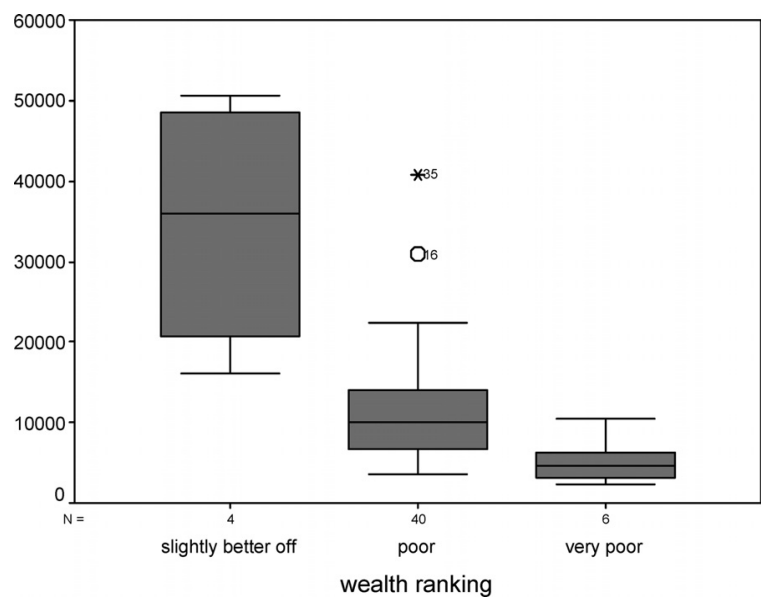

Figure 1 Cash income (\$ Mexican) and wealth ranking
For the large group of poor $(n=40)$, employment most of all, and subsidies, constitute the major sources of cash income. Other activities individually contribute little.

Sources of cash income for the small group of slightly better-off households $(n=4)$ are much more varied. Government subsidies linked to maize production again are significant, but are more or less matched by sales of maize from the milpa, retailing goods through a shop, paid labour and honey collection. The other activities in the livelihood portfolio contribute little cash income.

The single well-off family had a radically different income profile. Agricultural subsidies and sale of agricultural products together contribute as much as the retailing activities in the community. However, the main difference is from income through the commercial activities of transport and trading (of NTFPs).

\section{Data consistency and validation: multivariate analyses}

\section{Cluster analysis}

The purpose of the analysis was to understand the significance of the different cash income variables, and to assess the similarity between an objective classification of the sample and the self-reported wealth ranking classification.

Following the wealth ranking categorisation of four levels suggested by the communities, a fourcluster solution was imposed by the K-Means non-hierarchical method on cash income data giving the results presented in Table 4. The level of significance indicates those variables which best discriminated between cases. Sources contributing more than $50 \%$ of cash income were paid labour (cluster 2), and subsidies (cluster 4). Clusters 1 and 3 enjoyed cash income from more diverse sources.

\section{Cluster characterization and validation}

The characteristics of the four clusters were:

(1) Highly diversified households with significant trading activities.

(2) Households highly dependent on paid employment and subsidies. 
(a)

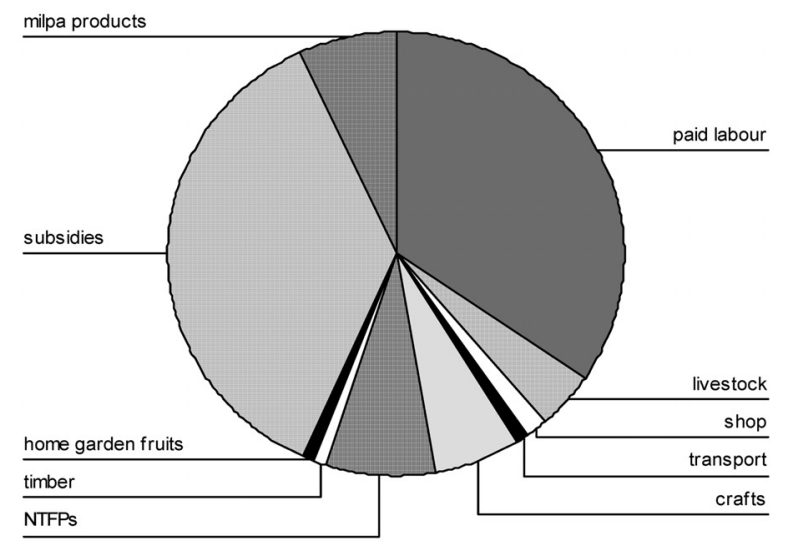

(b)

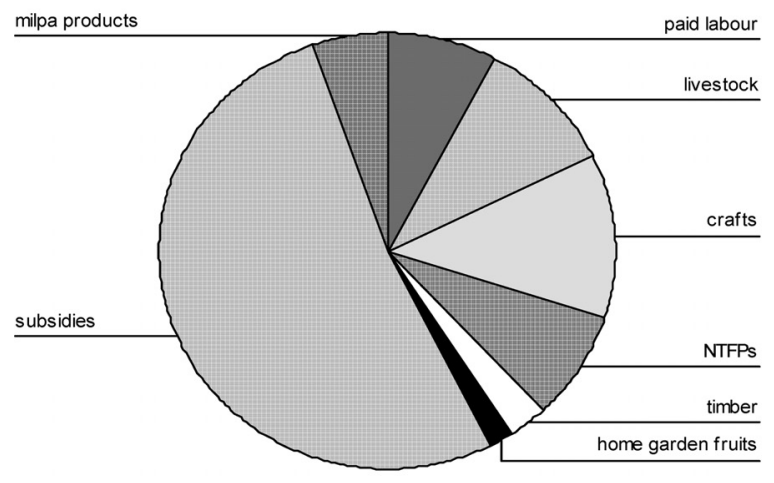

(d)

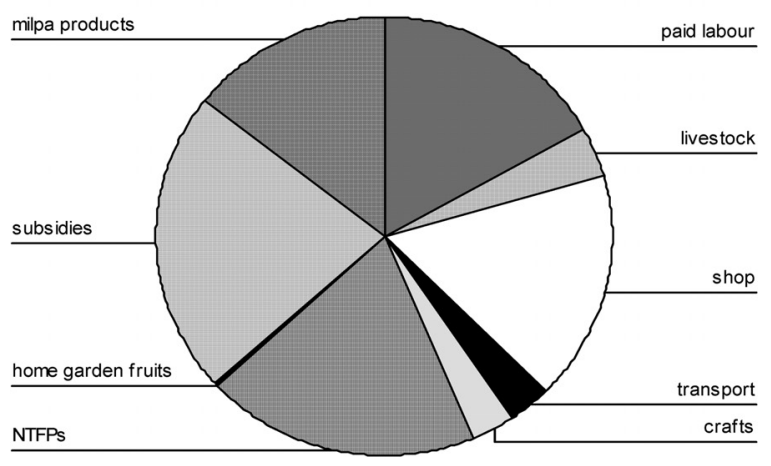

(c)

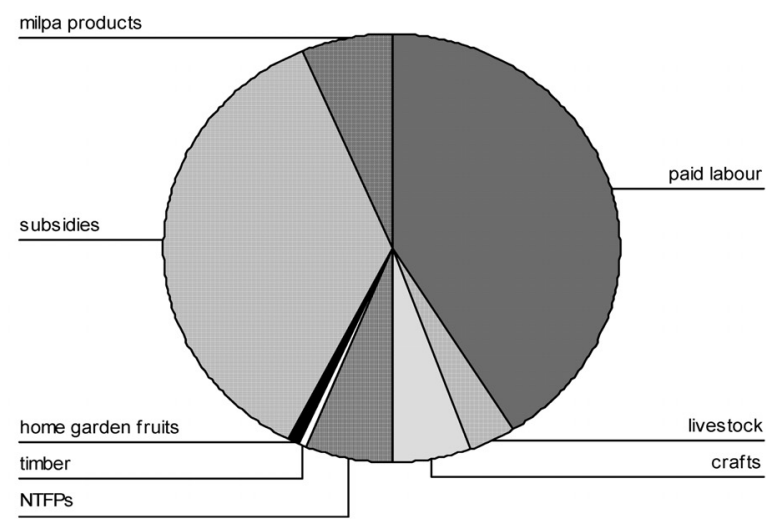

(e)

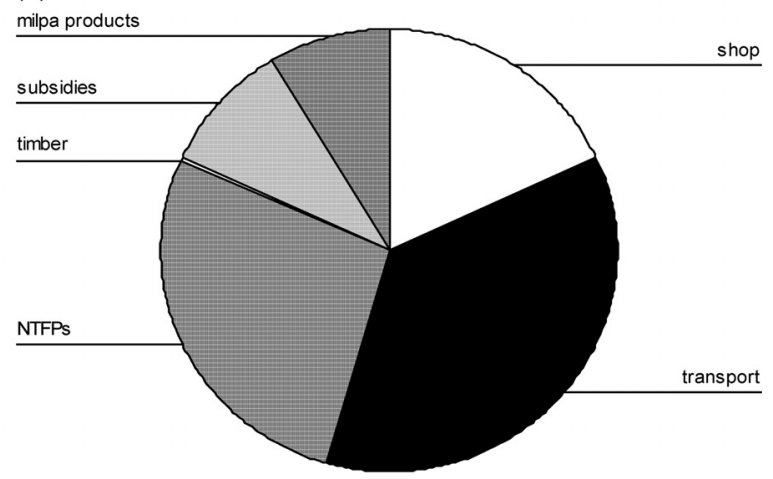

Figure 2 (a) Cash income sources: all cases. (b) Cash income sources: very poor $(n=6)$. (c) Cash income sources: poor $(n=40)$. (d) Cash income sources: slightly better-off $(n=4)$. (e) Cash income sources: well-off $(n=1)$ 
Table 4 Four cluster solution for diversity of cash income sources $(n=51)$

\begin{tabular}{|c|c|c|c|c|c|c|c|c|c|c|c|}
\hline \multirow[b]{2}{*}{ 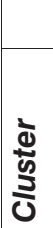 } & \multirow[b]{2}{*}{ 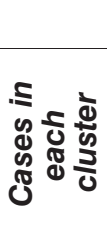 } & \multicolumn{10}{|c|}{ Proportion of income derived from different sources (\%) } \\
\hline & & $\frac{1}{\frac{0}{8}}$ & 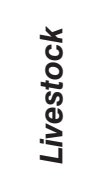 & $\frac{\stackrel{2}{c}}{\text { क }}$ & 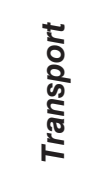 & $\underset{\mathbb{T}}{\mathbb{T}}$ & $\frac{\infty}{k}$ & है & 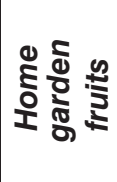 & $\begin{array}{l}\frac{7}{5} \\
\frac{0}{5} \\
\omega\end{array}$ & 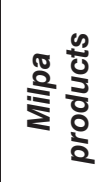 \\
\hline 1 & 3 & 4 & 1 & 24 & 16 & 0 & 25 & 0 & 0 & 9 & 20 \\
\hline 2 & 26 & 53 & 2 & 0 & 0 & 5 & 4 & 0 & 1 & 29 & 5 \\
\hline 3 & 6 & 25 & 7 & 0 & 0 & 25 & 6 & 0 & 0 & 32 & 4 \\
\hline 4 & 16 & 14 & 5 & 1 & 0 & 3 & 11 & 2 & 1 & 55 & 8 \\
\hline \multicolumn{2}{|c|}{ Significance } & 0.000 & 0.233 & 0.000 & 0.000 & 0.000 & 0.005 & 0.505 & 0.878 & 0.000 & 0.032 \\
\hline
\end{tabular}

(3) Households somewhat dependent on paid employment and subsidies, supplemented by other rural enterprises and craft production).

(4) Households very highly dependent on subsidies, with other income from paid employment and NTFPs.

Cross-tabulation of wealth ranking against the four-clusters (Table 5) compared the actual counts with the counts expected from the theoretical $\chi^{2}$ distribution, and gave the following result: a higher than expected representation of the poor in cluster 2, and a higher than expected representation of very poor in clusters 3 and 4; conversely, there were fewer than expected very poor in cluster 2. Statistical analysis of the cross-tabulation using the $\chi^{2}$ distribution was not valid because of the small sample size. Nevertheless, the pattern which emerged reinforced the notion of the dependence of the poor and of the very poor on paid employment and/or subsidies, and on minor rural enterprises.

\section{Factor analysis}

Factor analysis using the principal component extraction technique was conducted on 34 variables of social characteristics, assets, trading activities and income sources for the total of 51 households. The cut-off for retaining factors was eigenvalues $>1$. Variables were all metric except for education level of head of family (five levels from no education to completed secondary education) and number of beehives owned (four levels); and cash incomes derived from different sources (normalized to percentages). The analysis was conducted first using no rotation, and then using varimax rotation, with ten components isolated in each case. A high cut-off point of 0.700 for the significance of factor loadings was used because

Table 5 Cross-tabulation of cluster membership and wealth ranking

\begin{tabular}{||l|l|c|c|c|c||}
\hline \multirow{2}{*}{ Wealth ranking } & & \multicolumn{4}{|c||}{ Cluster number } \\
\cline { 3 - 6 } & & $\mathbf{1}$ & $\mathbf{2}$ & $\mathbf{3}$ & $\mathbf{4}$ \\
\hline Well-off & Actual count & 1.0 & 0.0 & 0.0 & 0.0 \\
\hline & Expected count & 0.1 & 0.5 & 0.1 & 0.3 \\
\hline Slightly better-off & Actual count & 2.0 & 0.0 & 1.0 & 1.0 \\
\hline & Expected count & 0.2 & 2.0 & 0.5 & 1.3 \\
\hline Poor & Actual count & 0.0 & 26.0 & 3.0 & 11.0 \\
\hline \multirow{2}{*}{ Very poor } & Expected count & 2.4 & 20.4 & 4.7 & 12.5 \\
\hline & Actual count & 0.0 & 0.0 & 2.0 & 4.0 \\
\hline & Expected count & 0.4 & 3.1 & 0.7 & 1.9 \\
\hline
\end{tabular}


of the small sample size (Hair et al., 1998). The Kaiser-Meyer-Olkin measure of sampling adequacy (0.514) was low but the Bartlett test of sphericity (significant at $99.9 \%$ level) suggested that the data set was appropriate for factor analysis. The same analyses were conducted on the sample excluding the outlier 'well-off' Mahas family $(n=50)$.

The rotated factors presented a more discriminating analysis of the data, with the greatest variation accounted for by (a) agribusiness; (b) participation in the maize economy; (c) honey production and trading. Factor characterizations are presented in Table 6. The first five factors accounted for $50.8 \%$ of the variation.

This factor analysis method of data reduction to understand the underlying structure gave results which were consistent with the wealth concepts underlying the wealth ranking procedure and added credence to the self-reporting approach to analysing livelihoods. The emergence of the factors isolated approximated to the predominant strategies of the groups ranked in decreasing wealth/increasing poverty, and therefore gave a good insight into wealth creation.

Table 6 Factor characterization $(n=50)$

\begin{tabular}{|l|c|l||}
\hline & $\begin{array}{c}\text { Variance } \\
\text { explained } \\
\text { (\%) }\end{array}$ & \multicolumn{1}{|c|}{ Characterization } \\
\hline Factor 1 & 15.84 & $\begin{array}{l}\text { Income from agribusiness } \\
\text { trading and transport }\end{array}$ \\
\hline Factor 2 & 13.15 & $\begin{array}{l}\text { Participation in the maize } \\
\text { economy }\end{array}$ \\
\hline Factor 3 & 8.27 & $\begin{array}{l}\text { Income from honey } \\
\text { production and sale }\end{array}$ \\
\hline Factor 4 & 7.16 & $\begin{array}{l}\text { Livestock ownership - } \\
\text { pigs }\end{array}$ \\
\hline Factor 5 & 6.38 & $\begin{array}{l}\text { Livestock ownership - } \\
\text { ducks and horses }\end{array}$ \\
\hline Factor 6 & 5.61 & $\begin{array}{l}\text { Agriculture and young } \\
\text { cattle }\end{array}$ \\
\hline Factor 7 & 5.20 & $\begin{array}{l}\text { Income from home } \\
\text { garden fruits and } \\
\text { migration }\end{array}$ \\
\hline Factor 8 & 4.37 & Income from shop \\
\hline Factor 9 & 4.14 & $\begin{array}{l}\text { Livestock ownership - } \\
\text { chickens }\end{array}$ \\
\hline $\begin{array}{l}\text { Factor } \\
10\end{array}$ & 3.73 & $\begin{array}{l}\text { Livestock ownership - } \\
\text { cows }\end{array}$ \\
\hline \hline
\end{tabular}

\section{Regression analysis}

The validity of the factor analysis was tested by conducting a regression of the poverty self-assessment by the wealth ranking procedure on the first five factors (accounting for $50.8 \%$ of the variation, Table 6). Use of the ordered probit model is the appropriate approach to take where the dependent and independent variables (or some of them) are categorical. The ordered probit results are presented in Table 7 . The relationships between wealth ranking and factors 1-3 (agribusiness, maize and honey) were found to be significant $(p<0.05)$. This result reinforced the validity of the cluster analysis which identified a group of better-off households with diverse trading characteristics, differentiated from others who were less engaged in markets.

\section{Discussion and implications}

\section{Livelihood strategies and assets}

Wealth ranking has served as a good proxy for understanding and assessing levels of poverty, reflecting not only the wealth-poverty self-perceptions of the communities, but also demonstrating a strong relationship between self-assessment and the results from analyses of the primary livelihood data. It is the endowment with productive economic assets, primarily agricultural and forest resources, as well as the strategies of individuals and the incentives and opportunities created through the external environment, that together determine the economic outcomes. The dominance of certain successful strategies seems clear. First, notwithstanding the ongoing debate about the sustainability of slash and burn practices in respect of soil and biodiversity conservation (de Frece, 2006; Eastmond \& Faust, 2006) milpa is a way of life for the Mayas. Besides the cultural significance of milpa, secure access to maize-producing land is a valuable asset and to work it is a viable strategy. Lack of land is associated with poverty not only because land enables maize to be produced and sold commercially, but because the area devoted to maize also attracts government subsidies.

Second, ownership of small livestock is also part of Mayan life, assets which are both culturally and 
Table 7 Regression analysis of wealth ranking and factor analysis

\begin{tabular}{|c|c|c|c|c|c|c|}
\hline \multicolumn{2}{|c|}{ Ordered probit estimates } & & \multirow{2}{*}{\multicolumn{2}{|c|}{$\begin{array}{c}\text { Number of obs }= \\
\operatorname{LR~chi}^{2}(5)=\end{array}$}} & 50 & \\
\hline & & & & & 30.21 & \\
\hline & & & \multicolumn{2}{|c|}{ Prob $>\mathrm{chi}^{2}=$} & 0 & \\
\hline Log likelihood & -16.643679 & & \multicolumn{2}{|c|}{ Pseudo $\mathrm{R}^{2}=$} & 0.4758 & \\
\hline wealthra | & Coef. & Std. err. & $z$ & $p>|z|$ & \multicolumn{2}{|c|}{ 95\% Conf. interval } \\
\hline fac1_1। & -2.144344 & 1.068304 & -2.01 & 0.045 & -4.238181 & -0.050507 \\
\hline fac2_1 | & -1.139244 & 0.471205 & -2.42 & 0.016 & -2.062788 & -0.215701 \\
\hline fac3_1। & -0.741412 & 0.328991 & -2.25 & 0.024 & -1.336222 & -0.096602 \\
\hline fac4_1। & -0.024113 & 0.276434 & -0.09 & 0.930 & -0.565914 & 0.517688 \\
\hline fac5_1| & 0.386520 & 0.221240 & 1.75 & 0.081 & -0.047103 & 0.820143 \\
\hline
\end{tabular}

economically important. Livestock enterprises not only can be integrated into sustainable production systems in Mexico, but are a critical means for animal genetic resource conservation per se (Drucker \& Anderson, 2005). Moreover, ownership of beehives gives entry into the (relatively) lucrative activity of honey production as well as providing important forest eco-services. Usufruct rights to fruit trees can be viewed similarly as 'ecological and economic win-wins' (Shaanker et al., 2004).

Third, on markets, the characteristics of the (a) outlier household, (b) the household membership of the 'trading' cluster and (c) the identification of the dominant 'agribusiness' factor all reiterate that engagement with diverse markets is associated with the upper scales of the wealth ranking. The outlier 'well-off' household demonstrates that access to markets is a function of assets: ownership of transport services; finance to assemble and sell products such as forest fruits, honey and maize; and 'leverage' assets that enable successful marketing, such as skills to run a wholesale/retail enterprise and to create commercial linkages to markets and other traders. It is this leverage which adds the value to the honey and forest fruits which are produced and collected by other poorer people. Such local market linkages are essential for economic sustainability, and the existing community-based natural resource management institutions, such as the actual tenurial and usufruct arrangements in Mahas and Poop, currently provide safeguards against over-exploitation by the 'trading' cluster members and resource degradation through slash and burn milpa.

\section{Poverty-exit strategies?}

The analyses have been more opaque about the poor and very poor, who are identified as those lacking the assets and opportunities of the 'betteroff'. Most poor households derive very small cash incomes from a range of rural activities with limited natural resource impacts. Nevertheless, poverty is associated with extreme dependence on maize subsidies linked to milpa. The maize economy serves poor households as a critical safety net, not just because of the subsistence element, but also because of the vital subsidy component that makes up so much of their cash income. This contrasts with the way the maize economy serves the better-off, as a commercial enterprise providing not just subsidies and subsistence but also the cash income that comes from trading milpa products.

As subsidies are a 'safety net', so too is paid employment something of a default strategy for the poor: it is the lack of other opportunities that compels households to engage in the labour market either locally or through migration to other regions. What differentiates the very poorest from the poor households is the lack of income from employment.

\section{Barriers to exit?}

The extent to which engaging in markets is a feasible poverty exit strategy raises more complicated questions. What factors determine engagement with markets? In order to understand better the 
asset-type barriers to market access, factor analyses were conducted including demographic variables from the wealth ranking criteria such as dependency ratios and certain 'non-productive' assets such as house type, and complementary assets such as education level. These variables had little explanatory power which is why they are unreported here. The value of wealth ranking, which is its descriptive richness (Table 2), is also its weakness, because it has failed to distinguish between the causes and consequences of poverty, and fails to give pointers to how assets are acquired.

The temporal perspective affects how one evaluates household characteristics, which may be as much a short-term consequence, as well as the long-term cause of poverty. Although demography did not explain access to markets, some demographic limitations and resulting time and energy pressures are fundamental barriers for the poorest households: a low rate of economically active persons, poor quality housing and services, low education level of household heads and high dependency ratios are likely to have an effect on poverty that is transmitted from one generation to the next. Thus, socio-demographic variables are related to wealth and poverty as both cause and consequence through generational effects. For these remote and natural resource-dependent communities, interventions such as the provision of business development services will not help the poorest engage in more remunerative livelihood strategies unless or until distributional issues affecting fundamental productive livelihood assets are addressed. Land is one such asset; hives are another, and possibly fruit trees. While the poorest have so few assets, their direct impact on, and potential contribution to, resource sustainability is minimal, and their contribution to natural resource exploitation takes effect through the labour market.

The existence of asset thresholds mean that markets work better for the village trading entrepreneurs with economic capital who were found to be better off than their poor suppliers. Nevertheless, 'trickledown' apparently works, inasmuch as the traders are the market-linkage mechanism whereby there are any commercial returns at all to the poorest, and their relative wealth creates an economic multiplier effect, for example through employment creation. Even where traders are few, they should not be vilified, therefore, but considered as necessary supply chain linkages providing market coordination in the absence of standard competitive market arrangements (Dorward et al., 2003). A policy of raising the level of productive assets rather than of constraining the strategies of local traders is an approach to business development that will more likely lead to better overall returns to communities. The competitive threat to the poor and small-scale enterprise arises not from within the local economy but from beyond, from the wider market environment, and through traders from outside the communities. It is arguable that the 'infant local economy' may need some sort of institutional protection and policy support, or a 'shark net', to allow local small enterprises to gain competitive scale before being subject to economic pressures from largescale traders from outside the locality (Poole, 2005a). Such institutions are relevant for the ejido, and through appropriate advocacy could be scaled up to the municipality level.

Engagement in labour markets is not a panacea. In a continent where remittances are massively important at the macro- and micro-level, social and cultural obstacles predispose these communities against migration. There is little support for engagement in distant labour markets as a preferred livelihood strategy, at least for now; rather, 'wealth' approximates more closely to 'stability' and successful integration into the local natural resources-based economy. As long as culture and identity create a persistent barrier to entry into wider labour markets, a cautious and nuanced view of the costs and benefits of migration is necessary (Hildebrandt \& McKenzie, 2005).

This research did not aim to study the changes in the cultural milieu of the Mayan communities. Nevertheless, anecdotal data from observation of the people, and evidence from other studies (de Frece, 2006) suggest that there is an accelerating process of encounter and conflict between traditional Mayan values and external cultural pressures arising from the mass media, schooling and a search for economic and social opportunities (Poole \& Álvarez Simán, 2006). There are gender and generation dimensions to this apparent choice of mestizaje - assimilation. The process of integration into the enveloping 'western' market economy in reality can also be one of cultural disintegration. This impending 'clash of cultures' 
Table 8 Livelihood strategy matrix

\begin{tabular}{||l|l|l||}
\hline \multicolumn{1}{||}{ Wealth ranking } & \multicolumn{1}{|c|}{ Livelihood strategies } \\
\cline { 2 - 3 } & \multicolumn{1}{|c|}{ Critical and current } & \multicolumn{1}{c|}{ Feasible opportunities } \\
\hline Well-off & $\begin{array}{l}\text { Diverse forms of } \\
\text { agribusiness }\end{array}$ & $\begin{array}{l}\text { Output marketing and employment-generating activities } \\
\text { Retail of consumer goods and services }\end{array}$ \\
\hline Slightly better-off & $\begin{array}{l}\text { Diverse agribusiness } \\
\text { Local employment }\end{array}$ & $\begin{array}{l}\text { Output marketing and employment-generating activities } \\
\text { Support to develop agricultural production } \\
\text { Local labour market information } \\
\text { Retail of consumer goods and services }\end{array}$ \\
\hline Poor & $\begin{array}{l}\text { Transfer: maize subsidies } \\
\text { Local employment }\end{array}$ & $\begin{array}{l}\text { Support to develop honey production, small livestock } \\
\text { and crafts } \\
\text { Local labour market information }\end{array}$ \\
\hline Very poor & $\begin{array}{l}\text { Transfer: maize subsidies } \\
\text { Small household-based } \\
\text { rural enterprises }\end{array}$ & $\begin{array}{l}\text { Support to develop honey production, small livestock } \\
\text { and crafts }\end{array}$ \\
\hline
\end{tabular}

will affect both concepts and levels of poverty, inter alia.

\section{Interventions and exit paths?}

Anti-poverty programmes fall within the competence of government and various non-governmental organizations. For the different wealth groups in Mahas and Poop, Table 8 summarizes current strategies and those which are likely to be feasible within the expected household constraints, and which can be incorporated into local targeting programmes.

For the well-off and slightly better-off, interventions suppose primarily information and advice aimed at creating greater multiplier effects in the communities. Consideration can also be given to creating a greater market for consumer goods and services (such as household utilities and information technology facilities) that might create incentives for increasing output and improvements to the quality of life of the poor. Traders should be subject to local institutions to restrain unsustainable exploitation of natural resources.

For the poor and very poor, options are fewer but more critical, most of all the government maize subsidies. There is no expectation that these payments will become means-targeted, and anyway, they already constitute an (albeit imperfect and indirect) transfer to labour employed in agricultural production. Support to rural activities supposes not just information and advice, but time-bound transfers and loans to create a broader asset base, and long-term support to overcome the other manifestations of persistent inter-generational poverty.

Finally, it is worth reiterating that national and regional inequalities are not all that need to be taken into account in anti-poverty policies and programmes for sustainable development. In marginalized communities such as Mahas and Poop intra-community heterogeneity will influence the impact of policy interventions (Elbers et al., 2004). Addressing the poverty and sustainability issues of the poorest quintile in any similar population will require a detailed understanding of people's assets, strategies, and of the local context, before appropriate sustainability and poverty exit pathways can be devised and tested.

\section{Notes}

1. http://millenniumindicators.un.org/unsd/mi/mi_ goals.asp.

2. For example, child poverty in the United States in 2003 was above the rates of most industrialized countries, was substantially higher in rural areas, and was characterized by important regional and ethnic disparities (USDA Economic Research Service, 2005).

3. $\$=$ Mexican peso, 2002 values. $£ 1=\$ 13$ Mexican or US $\$ 1=\$ 9$ Mexican (March 2002). 


\section{Acknowledgements}

This publication is an output from a research project funded by the United Kingdom Department for International Development (DFID) for the benefit of developing countries. The views expressed are not necessarily those of DFID [R7349, Forestry Research Programme].

The collaboration of the Departmento de Biología of the Universidad Autónoma de Yucatán and the NGO Hombre Sobre la Tierra is gratefully acknowledged.

\section{References}

Andolina, R. (2003) The sovereign and its shadow: Constituent assembly and indigenous movement in Ecuador. Journal of Latin American Studies 35 (4), 721-750.

Besley, T. and Burgess, R. (2003) Halving global poverty. Journal of Economic Perspectives 17 (3), 3-22.

Chen, S. and Ravallion, M. (2004) How have the world's poor fared since the early 1980s? World Bank Policy Research Working Paper 3341. Washington DC: World Bank.

de Frece, A. (2006) Power/knowledge and identity: Development interventions in a Maya village. Unpublished PhD, Centre for Environmental Policy, Wye Campus, Imperial College London, London.

de Janvry, A. and Sadoulet, E. (2000) Rural poverty in Latin America: Determinants and exit paths. Food Policy 25 (4), 389-409.

Dorward, A., Poole, N.D., Morrison, J.M., Kydd, J.K. and Urey, I. (2003) Markets, institutions and technology: Missing links in livelihoods analysis. Development Policy Review 21 (3), 319-332.

Drucker, A.G. and Anderson, S. (2005) Economic analysis of animal genetic resources and the use of rural appraisal methods: Lessons from Southeast Mexico. International Journal of Agricultural Sustainability 2 (2), 77-97.

Eastmond, A. and Faust, B. (2006) Farmers, fires, and forests: A green alternative to shifting cultivation for conservation of the Maya forest? Landscape and Urban Planning 74 (3-4), 267-284.

Edwards, C. (1986) The human impact on the forest in Quintana Roó, Mexico. Journal of Forest History July, 120-127.

Elbers, C., Lanjouw, P., Mistiaen, J.A., Özler, B. and Simler, K. (2004) On the unequal inequality of poor communities. World Bank Economic Review 18 (3), 401-421.

Fuentes, R. and Montes, A. (2004) Mexico and the millennium development goals at the subnational level. Journal of Human Development 5 (1), 97-120.
Gauthier, R. and Poole, N.D. (2003) Enhancing the roles of forest fruits in sustaining livelihoods of forest margin communities. Final Technical Report, Project R7349, Department for International Development Forestry Research Programme. Wye, Kent: Imperial College London.

Gómez-Pompa, A. (1987) On Mayan silviculture. Mexican Studies/Estudios Mexicanos 1 (1), 1-17.

Gómez-Pompa, A. and Kaus, A. (1990) Traditional management of tropical forests in Mexico. In A.B. Anderson (ed.) Alternative to Deforestation: Steps Toward Sustainable Use of the Amazon Rainforest. New York: Columbia University Press.

Grandin, B.E. (1988) Wealth Ranking in Smallholder Communities: A Field Manual. London: Intermediate Technology Publications.

Haggar, J., Sosa, M., Díaz, B., Hernández, G., Contreras, J.A. and Uc, C. (2005) Adaptation of agroforestry systems in South-Eastern Mexico through integration of farmer and bioeconomic evaluations. International Journal of Agricultural Sustainability 2 (3), 154-166.

Hair, J.F., Anderson, R.E., Tatham, R.L. and Black, W.C. (1998) Multivariate Data Analysis. New Jersey: Prentice-Hall.

Hentschel, J. and Waters, W.F. (2002) Rural poverty in Ecuador: Assessing local realities for the development of anti-poverty programs. World Development 30 (1), 33-47.

Hildebrandt, N. and McKenzie, D.J. (2005) The effects of migration on child health in Mexico: 35. Policy Research Working Paper. On WWW at http://web. worldbank.org/servlets/ECR? entityID =000012009_ 20050429125802\&collection=IMAGEBANK\&site $\mathrm{PK}=615158$. Accessed September 2007. Washington DC: World Bank.

IFAD (No date) Indigenous Peoples and Rural Poverty. On WWW at http://www.ruralpovertyportal.org/ english/topics/indigenous/index.htm. Accessed 21.05.07.

INEGI (2000) XII Censo General de la Población y Vivienda. Principales resultados por localidad. On WWW at http://www.inegi.gob.mx: Instituto Nacional de Estadística, Geografía e Información.

Martínez, L. (2004) El campesino andino y la globalización a fines del siglo (una mirada sobre el caso ecuatoriano). Revista Europea de Estudios Latinoamericanos $y$ del Caribe 77 (Oct), 25-40.

Nath, T.K., Inoue, M. and Chakma, S. (2006) Shifting cultivation (jhum) in the Chittagong Hill Tracts, Bangladesh: Examining its sustainability, rural livelihood and policy implications. International Journal of Agricultural Sustainability 3 (2), 130-142.

Nicklin, C., Rivera, M. and Nelson, R. (2006) Realizing the potential of an Andean legume: Roles of marketled and research-led innovations. International Journal of Agricultural Sustainability 4 (1), 61-78.

Organisation for Economic Co-operation and Development and United Nations Development Programme. (2002) Sustainable Development Strategies: A Resource Book (358 pp). Paris and New York: OECD and UNDP. 
Poole, N.D. (2004) Perennialism and poverty reduction: Knowledge strategies for tree and forest products. Development Policy Review 22 (1), 49-74.

Poole, N.D. (2005a) Making markets work for the rural poor (Hacer funcionar los mercados a beneficio de los pobres rurales). Invited paper presented at the international conference Reducción de la Pobreza en Centroamérica: Fortalecimiento de Servicios Técnicos, Empresariales y Financieros, 11-13 April. Turrialba, Costa Rica: CATIE (Centro Agronómico Tropical de Investigación y Enseñanza).

Poole, N.D. (2005b) Poverty, inequality and ethnicity: A note to policy makers on Latin America. Eurochoices 4 (3), 44-49.

Poole, N.D. and Álvarez Simán, F. (2006) La tecnología, el acceso a la información y la inserción social y económica: el impacto de las telesecundarias en las comunidades indígenas de Chiapas. Paper presented at the Séptimo Foro de Evaluación Educativa, San Luis Potosí, Mexico, 24-26 October.

Poole, N.D. and Penrose Buckley, C. (2006) Innovation challenges, constraints and opportunities for the rural poor. Background Paper for the International Fund for Agricultural Development (IFAD), Rome. On WWW at http://www.ifad.org/events/gc/29/panel/ e/poole.pdf. Accessed September 2007. Wye, Kent, UK: Imperial College London.

Ravallion, M., Datt, G. and van de Walle, D. (1991) Quantifying absolute poverty in the developing world. Review of Income and Wealth 37 (4), 345-361.

Ravallion, M. (2004) Pro-poor growth: A primer. Research Working Paper Number 3242: 28. Washington, DC: World Bank.

Shaanker, R.U., Ganeshaiah, K.N., Krishnan, S., Ramya, R., Meera, C., Aravind, N.A., Kumar, A., Rao, D., Vanraj, G., Ramachandra, J., Gauthier, R., Ghazoul, J., Poole, N.D. and Chinnappa Reddy, B.V. (2004) Livelihood gains and ecological costs of NTFP dependence: Assessing the roles of dependence, ecological knowledge and market structure in three contrasting human and ecological settings in south India. Environmental Conservation 31 (3), 242-253.

Tilley, V.Q. (2002) New help or new hegemony? The transnational indigenous peoples' movement and Being Indian' in El Salvador. Journal of Latin American Studies 34 (3), 525-554.

USDA Economic Research Service (2005) Rural Children at a Glance. Economic Information Bulletin Number 1, March. Washington DC: United States Department of Agriculture.

van Cott, D.L. (2003) From exclusion to inclusion: Bolivia's 2002 elections. Journal of Latin American Studies 35 (4), 751-775.

Villafuerte Solís, D. (2005) Rural Chiapas ten years after the armed uprising of 1994: An economic overview. Journal of Peasant Studies 32 (3), 461-483.

Wadsworth, J., Richards, M., Maxwell, S., Baumeister, E., Colindres, I., Laforge, M., López, M., Pino, H.N., Sauma, J.P. and Walker, I. (2004) Opciones Para Reducir la Pobreza Rural en Centroamérica. San José, Costa Rica: Unidad Regional de Asistencia Técnica.

Washbrook, S. (2005) The Chiapas uprising of 1994: Historical antecedents and political consequences. Journal of Peasant Studies 32 (3-4), 417-449.

Wolfensohn, J.D. and Bourguignon, F. (2004) Development and poverty reduction: Looking back, looking ahead. Paper prepared for the 2004 Annual Meeting of the World Bank and the IMF, October. Washington DC: World Bank.

World Bank (1990) Poverty. World Development Report 1990. New York: Oxford University Press.

World Bank Institute Poverty and Growth Blog. (No date) Indigenous and Tribal People and PRSPs. On WWW at http://pgpblog.worldbank.org/indigenous_ and_tribal_people_and_prsps. Accessed 21.05.07.

World Commission on Environment and Development. (1987) Our Common Future. Oxford: Oxford University Press. 